\title{
MRIM (Multiple Representation-Based Interactive Multimedia): Is it Good to Improve Students' Scientific Literacy?
}

\author{
Arief Muliandi $^{1 *}$, Nur Endah Susilowati ${ }^{2}$, Siti Rahmah $^{3}$, Sri Wahyuni ${ }^{4}$, Dadi Rusdiana ${ }^{5}$ \\ 1,2,3,4,5 Departemen Pendidikan Fisika, Universitas Pendidikan Indonesia, Bandung, Indonesia \\ *Coressponding author: arief.muliandi306@upi.edu
}

\author{
Article History: \\ Received: april 04, 2021 \\ Revised: mei 21, 2021 \\ Accepted: juni 02, 2021 \\ Published: juni 24, 2021
}

Keywords: Interactive multimedia, multiple representation, multiple representation-based interactive multimedia, student's scientific literacy

\begin{abstract}
The low scientific literacy of Indonesian students attracts the attention of Indonesian education practitioners to continue researching the right solution to overcome it. With the help of multi-representation interactive multimedia, this research facilitated students to learn actively and independently. The aim of this research was to develop multi representation-based interactive multimedia (MRIM) to improve students' scientific literacy skills. The research method is research and development with 4D model (define, design, develop, and disseminate), and data analysis using Paired t-test. The define stage for problem identification and analyzing needs, we involved a sample of 30 students from 8th grade and 2 science teachers. At the design stage, a multimedia framework and scientific literacy instruments were created. In the develop stage, multimedia was tested on 1 lecturer as a reviewer, and 3 teachers, and then the media was tested on a small group, consisted of 7 students of 7th grade of SMPQT Al-Hamidiyah with random selection. And at the disseminate stage, all data that has been processed is then written in the form of articles which will then be published. The results of the expert judgment test stated that the multimedia is feasible to use, while the small group test results showed that this multimedia can improve students' scientific literacy skills with a significance value of $0.000<0.05$ (based on the results of the paired t-test). In conclusion, this interactive multimedia is very suitable for use in learning and can improve students' scientific literacy skills.
\end{abstract}

\section{INTRODUCTION}

Science subjects are one of the subjects that must exist at every school level, it cannot be denied that in science subjects students will be presented with three constituent subjects, biology, chemistry and physics (Prastikawati et al., 2020). At the junior high school level, science is expected to make students recognize and be able to analyze scientific knowledge so that students have the ability to organize, analyze and interpret quantitative data and scientific information, or what is often referred to as scientific literacy (Gormally et al., 2012). By having scientific literacy skills, junior high school students will have knowledge of general procedures and practices related to how to apply, critique, and create science itself (Kementerian Pendidikan dan Kebudayaan, 2017).

The application of scientific literacy in science learning is expected to provide knowledge and understanding of science so that junior high school students are able to understand science reading so that the learning outcomes of science subjects for junior high school students are no longer below the minimum completeness criteria (Sari et al., 2020). The topic of solids and liquids pressure contains important principles that are beneficial to the environment(Makhrus et al., 2021; Rahmawati et al., 2016). The 
training of scientific literacy is also important to support the achievement of learning outcomes and student learning activities in the classroom (Kristyasari et al., 2018).

Scientific literacy needs to be mastered by junior high school students because scientific literacy refers to scientific knowledge and students are required to use this knowledge to identify questions, gain new knowledge and so that students can explain scientific phenomena that draw evidence-based conclusions about the problems that are in the concepts they are studying related to science, in this case, is the solids and liquids pressures (Organisation for Economic Cooperation and Development (OECD), 2016). This is important to advance the thinking skills of junior high school students, especially on the topic of solid and liquid pressure. The basic principle of scientific literacy is that it must be contextual, must be in accordance with the times, must be in accordance with quality standards in learning that are in line with 21 st-century learning, integrated with various other literacies so that it can be collaborative and participatory (Kementerian Pendidikan dan Kebudayaan, 2017).

Scientific literacy also helps junior high school students to form patterns of thought, behavior, and also build students' character to care and be responsible for themselves, society, the universe, and the problems that today are very dependent on technology (Kementerian Pendidikan dan Kebudayaan, 2017). Strengthening scientific literacy among junior high school students can be done by using interactive multimedia in learning. Because scientific literacy refers to the awareness of junior high school students about how science and technology can shape material and intellectual (Organisation for Economic Cooperation and Development (OECD), 2016). Interactive multimedia is a learning media that can be accessed using computer technology or gadgets (Widodo et al., 2020).

Interactive multimedia can attract students' attention and facilitate students in the learning process. Based on the results of a preliminary study conducted by researchers, from 30 junior high school students, $92 \%$ of students stated that they were interested and needed interactive multimedia. Due to the combination of several media displayed, such as images, text, animation, sound, video, and others, it can make learning more fun and meaningful and eliminate boredom in learning, especially science lessons on solid and liquid pressure materials. (Adhitama, Sujadi, \& Pramudya, 2018, hal. 2). Thus, interactive multimedia becomes an ideal and practical medium to be used in the learning process, but still must be in accordance with the indicators (Ariani et al., 2020).

Interactive multimedia is equipped with a controller which means that students can operate and run interactive multimedia by themselves, so that students can choose what concept or stage they want for the next process in learning an interactive multimedia form of material (Atmawarni, 2011). Interactive multimedia packages the learning process to be more interesting, students become more active, so that the use of learning time becomes more effective and efficient so that it affects the quality of student learning can be improved anywhere and anytime, motivation and student learning attitudes can also be improved (Hakim et al., 2020).

The application of interactive multimedia trains students to have multirepresentation abilities, because multirepresentation helps junior high school students understand the concepts presented in interactive multimedia which will later affect students' scientific literacy (Murtono, Setiawan \& Rusdiana, 2014). The role of multi-representation is as a complement to information from a concept 
that is being studied or that has been studied, as an interpretation that limits students so that there is no misinterpretation in understanding concepts or questions, and the existence of multiple representations builds a deeper understanding of the concepts being studied (Sarwi et al., 2020).

It is important to apply multiple representations in the form of scientific literacy described in interactive multimedia, or in other forms, because through multiple representations, junior high school students can build concepts and overcome problems that arise when students study science, one of which is when students study material pressure on substances and substances liquid (Furwati et al., 2017). Not only that, but multirepresentation is also considered the key to learning science, because it can connect concepts into other forms such as verbal or physical forms, pictures, and even in the form of mathematical equations (Furwati et al., 2017).

Apart from the importance of scientific literacy for students as previously explained, presentations related to scientific literacy, interactive multimedia, and multi-representation became a special interest for us. So we conducted a study to identify the scientific literacy skills of junior high school students in the subject of solid and liquid pressure when using multi-representationbased interactive multimedia. The results of identification and measurement are expected to be a source or reference for readers to make or develop further research.

\section{METHODS}

This research is a development research with a 4D development model (Mahbub et al., 2016; Shabrina \& Kuswanto, 2018; Syafitri et al., 2018). The 4D development model consists of 4 main stages, Define, Design, Develop and Disseminate (Istiyono, 2018; Ristanto et al., 2020; Yanti et al., 2019). The flow of this research can be seen in Figure 1.



Figure 1. Research Procedure

\section{Define}

At this stage, the researchers conducted a needs analysis by giving questionnaires to 30 students of SMPQT al-Hamidiyah (8th grade) regarding the needs of interactive multimedia. From 30 students, 92\% of students stated that they needed interactive multimedia in online learning to make learning more fun and meaningful. Moreover, based on the results of a needs 
analysis questionnaire given to 2 science teachers at SMPQT Al-Hamidiyah, they stated that they needed interactive multimedia on substance pressure and its application in everyday life. Not only the students, but the teachers also revealed that online learning, so far, has not been effective because learning tends to take place in one direction with the teacher as the only source of information. Therefore, interactive multimedia is needed which not only acts as a learning resource but can provide feedback to students so that learning can take place in two directions (interactive).

\section{Design}

At this stage, researchers develop a multimedia research content framework, arrange materials, images, videos, and simulations that will be presented, develop scientific literacy instruments and design interactive multimedia. The scientific literacy instrument used is an instrument in the form of an essay which is adopted from Latifah et al., (2019). This instrument uses the scientific literacy indicators by PISA, namely identifying scientific issues, explaining phenomena scientifically, and using scientific evidence. Examples of scientific literacy instruments used in this study can be seen in table 1 This instrument uses scientific literacy indicators by PISA, namely identifying scientific issues, explaining phenomena scientifically, and using scientific evidence. Examples of scientific literacy instruments used in this study can be seen in table 1.

Table 1. Examples of Scientific Literacy Instruments

\begin{tabular}{|c|c|c|}
\hline $\begin{array}{c}\text { Scientific } \\
\text { Literacy } \\
\text { Indicator }\end{array}$ & Question & Answer \\
\hline \multirow[t]{2}{*}{$\begin{array}{l}\text { Explaining } \\
\text { phenomena } \\
\text { scientifically }\end{array}$} & 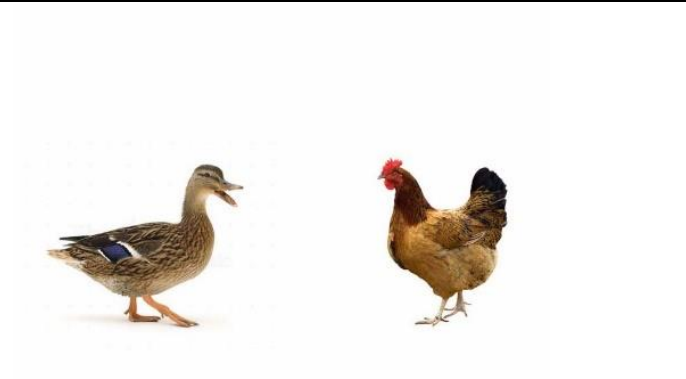 & $\begin{array}{l}\text { Based on the concept of } \\
\text { pressure, the amount of pressure } \\
\text { experienced by a plane on a solid } \\
\text { object is proportional to the } \\
\text { magnitude of the force and } \\
\text { inversely proportional to the area } \\
\text { of the compressive field. } \\
\qquad P=\frac{F}{A}\end{array}$ \\
\hline & $\begin{array}{l}\text { Dina watched the chickens and ducks walking } \\
\text { in the mud on her grandfather's farm. Chickens } \\
\text { seem to have difficulty moving their feet, but } \\
\text { ducks can walk very quickly. If they both have } \\
\text { the same mass, why does this happen? } \\
\text { Explain the reason scientifically by relating it to } \\
\text { the concepts you have learned! }\end{array}$ & $\begin{array}{l}\text { So in the case of chickens and } \\
\text { ducks in the picture, the duck's } \\
\text { feet do not go into the mud } \\
\text { because the pressure area is } \\
\text { wider so that the pressure } \\
\text { exerted by the duck's body } \\
\text { weight is smaller. The duck's } \\
\text { feet have a membrane that } \\
\text { increases the area of the pressure } \\
\text { area into the mud. Unlike the } \\
\text { case with chickens, the narrow } \\
\text { surface of the chicken feet } \\
\text { makes the pressure exerted by its } \\
\text { body weight become large }\end{array}$ \\
\hline
\end{tabular}

The problem above presents a phenomenon that is very closely related to students' lives, and students are required to provide a scientific explanation regarding the incident, why duck feet are not easily trapped in the mud while chicken feet are often stuck when walking in the mud. This can be explained by the concept of 
pressure which is directly proportional to the cross-sectional area.

\section{Develop}

At this stage, an expert assessment (1 lecturer and 3 teachers) is carried out. At the initial stage, a direct assessment is carried out in the form of a presentation to the lecturer. There are content revisions such as the preparation of simulations and materials that should not write too many formulas, the goal is that students can find and build their own concepts. Then after the revision, the product was tested on 3 science teachers. The three teachers provided input related to media and materials. A recap of validator suggestions can be seen in tables 2 and 3 .

Table 2. Interactive multimedia content improvement suggestions

\begin{tabular}{|c|c|c|}
\hline Validator Code & Suggestion & Action \\
\hline \multirow[t]{3}{*}{ Validator 1} & There are some typos, very annoying. & Already fixed \\
\hline & $\begin{array}{l}\text { Use pictures that are closer to the } \\
\text { child's life. }\end{array}$ & Already fixed \\
\hline & Have not seen multi-representation. & Already fixed \\
\hline \multirow[t]{4}{*}{ Validator 2} & $\begin{array}{l}\text { Change some of the pictures into } \\
\text { pictures that are closer to student life, } \\
\text { for example in hydrostatic, use } \\
\text { pictures of duck feet and chicken feet. }\end{array}$ & Already fixed \\
\hline & $\begin{array}{l}\text { We recommend the original } \\
\text { explanation video from the media } \\
\text { developer. }\end{array}$ & Already fixed \\
\hline & $\begin{array}{l}\text { It is better, to reflect on the answer, } \\
\text { use } \\
\text { understanding }\end{array}$ & Already fixed \\
\hline & $\begin{array}{l}\text { Give creative questions, such as } \\
\text { games and so on, that make students } \\
\text { interested in learning. }\end{array}$ & Already fixed \\
\hline \multirow[t]{2}{*}{ Validator 3} & Some typos, please fix. & Already fixed \\
\hline & $\begin{array}{l}\text { Give creative questions, such as } \\
\text { games and so on, that make students } \\
\text { interested in learning. }\end{array}$ & Already fixed \\
\hline
\end{tabular}

Table 3. Interactive multimedia display improvement suggestions

\begin{tabular}{lll}
\hline Validator Code & Critics & Suggestions \\
\hline Validator 1 & $\begin{array}{l}\text { Figure on the hydrostatic pressure } \\
\text { section }\end{array}$ & $\begin{array}{l}\text { To represent the initial concept, it } \\
\text { should be replaced with a picture of a } \\
\text { diver, because it is interesting and } \\
\text { close to students' lives } \\
\text { We recommend using videos recorded } \\
\text { bideos }\end{array}$ \\
Vouble function navigation key & $\begin{array}{l}\text { It's very good, but you should pay } \\
\text { attention to the navigation section, } \\
\text { there is a next button, there is a next, } \\
\text { why double navigation like that }\end{array}$ \\
& $\begin{array}{l}\text { Audio in each section } \\
\text { It's better if the audio section for } \\
\text { wrong and right questions is made } \\
\text { different } \\
\text { It's been very good and represents } \\
\text { learning well }\end{array}$ \\
\hline
\end{tabular}

After making improvements, the results of the validator's assessment are calculated and interpreted in a qualitative form. Guidelines for interpreting media feasibility can be seen in table 4 below. 
Table 4. Feasibility Interpretation

\begin{tabular}{cc}
\hline Skor $(\%)$ & Interpretation \\
\hline $80 \leq x \leq 100$ & Very Feasible \\
$60 \leq x<80$ & Feasible \\
$40 \leq x<60$ & Moderate \\
$20 \leq x<40$ & Not Feasible \\
$0 \leq x<20$ & Ignore \\
\hline After the media & was declare
\end{tabular}

suitable for use, a small group trial was conducted on 7 students who were randomly selected from 7th grade of SMPQT Al-Hamidiyah. After the trial was conducted, an evaluation test was conducted to determine the effect of this interactive multimedia on students' scientific literacy. Furthermore, the test results were analyzed by Paired t-test through SPSS 25 software (Wahyudi et al., 2020; Zhou, 2021).

\section{Disseminate}

At this stage, all data that has been processed is then written in the form of articles which will then be published.

\section{RESULTS AND DISCUSSION}

The results of this development research include: (1) The results of the validation of the feasibility questionnaire by experts which include the validation of media and materials (2) The results of a small-group trial with 7 students (3) The results of the pre-test before using interactive media and the results of the post-test. test after using interactive media

\section{Define}

At the beginning of this study, a needs analysis was carried out by distributing online questionnaires in several junior high schools in Pati Regency. It was found that the average results of the evaluation of
Substance Pressure and Its Application in Daily Life Class 8 Class 2019-2020 at Junior High Schools in Pati Regency did not reach the standard. The low result of the National Examination score has a relationship with student learning difficulties. Which student learning difficulties are influenced by several factors: (1) internal factors in the form of aspects of talent, interest, motivation and intelligence, (2) external factors in the form of school facilities, teachers, infrastructure and student activities (Haqiqi, 2018).

Meanwhile, based on the results of the questionnaire analysis, it was found that students felt less interested in participating in learning, teachers did not take advantage of existing learning media, and the unavailability of interactive learning media that could facilitate students to learn actively and independently. So based on these findings, the researchers developed Multirepresentation-Based Interactive Media Assisted E-learning to Improve Science Literacy for Grade 8 Middle School Students. The aim is to provide interesting and innovative learning media, so as to increase students' motivation to be more active in learning; provide learning media that can facilitate students to learn independently, and provide learning media that can train students' scientific literacy skills (through simulations and exercises).

\section{Design}

In this section, an outline of the learning media is made, then a flowchart and storyboard are made. The initial framework of the media can be seen in Figure 2 below. 


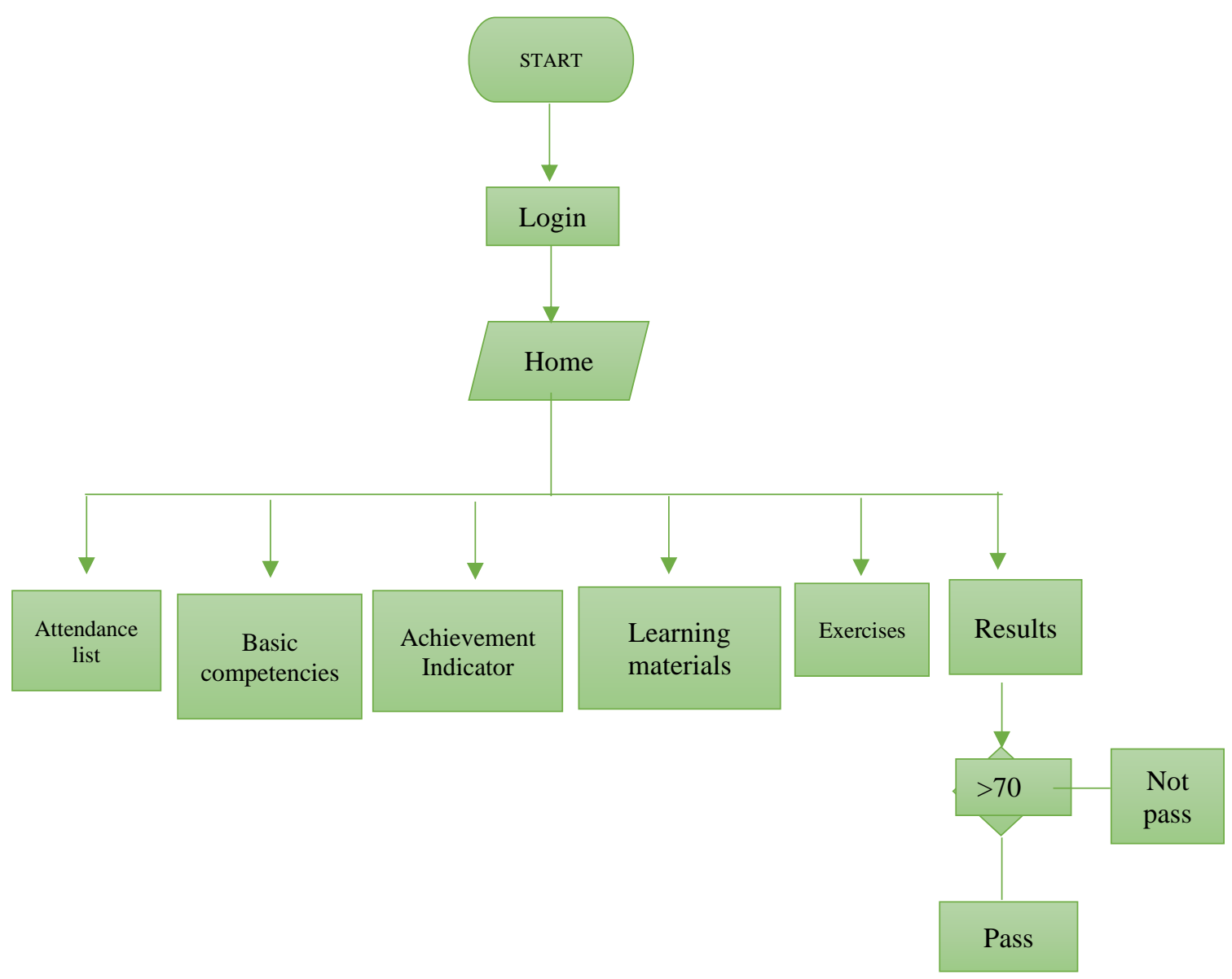

Figure 2. Multi Representation-Based Interactive Media Flowchart

As for the storyboard description of interactive media to improve scientific each content in multi-representation-based literacy is described in Table 5.

Table 5. Storyboard description of Multi-Representation-Based Interactive Media






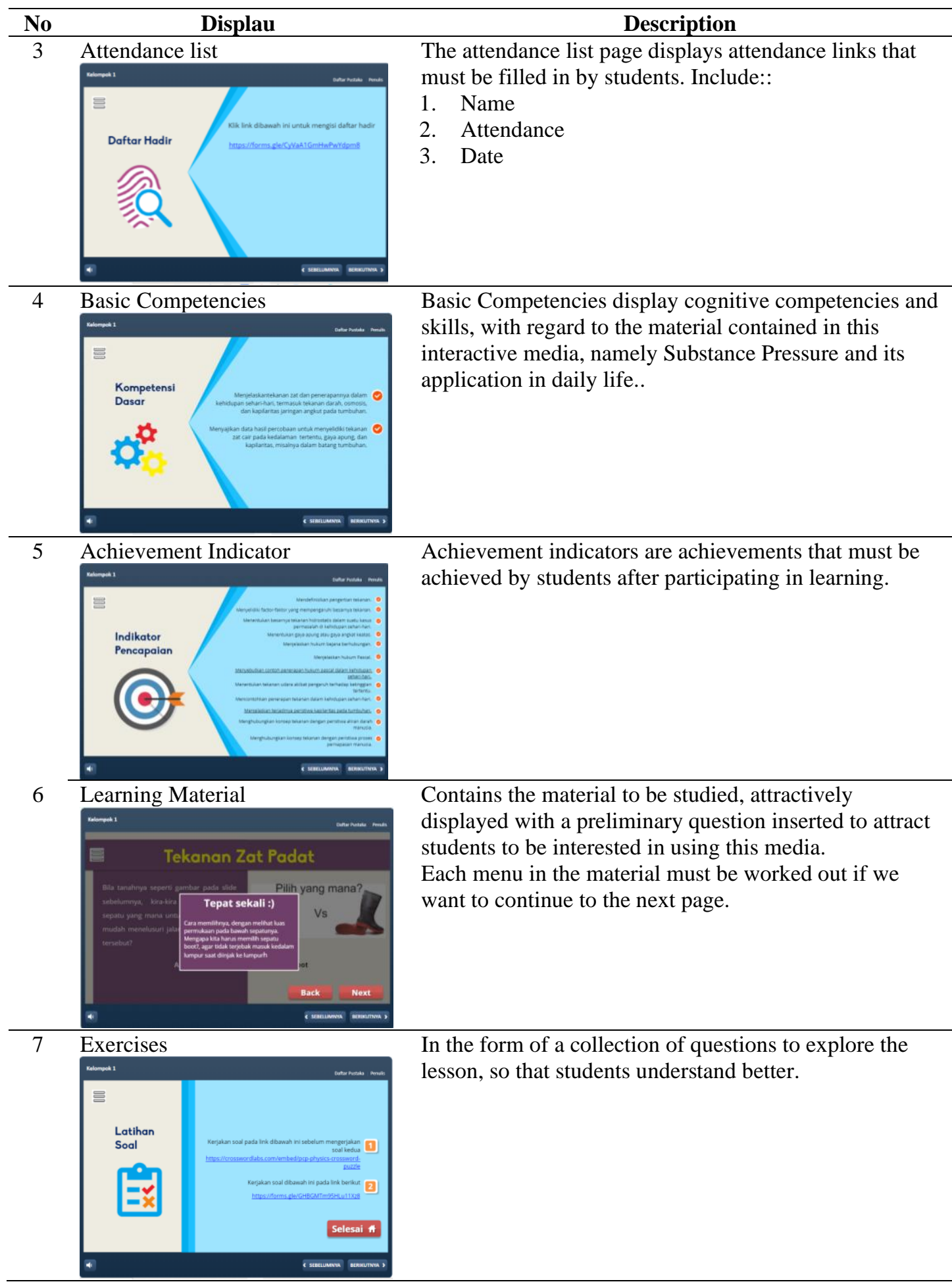

\section{Develop}

\section{Validation Stage}

In the development section, we created a Multi representation-Based Interactive Media to Improve Science Literacy by using the Articulate Storyline software application. Once completed, the media is validated by the validators including content validator and media validator. The validator is natural science teachers.

The results of content validation by the three validators showed that the media was very feasible with an average 
percentage of $83.8 \%$. In detail shown by Table 6.

Table 6. Content validation results by the three validators

\begin{tabular}{cccc}
\hline & $\begin{array}{c}\text { Validator } \\
\mathbf{1}\end{array}$ & $\begin{array}{c}\text { Validator } \\
\mathbf{2}\end{array}$ & $\begin{array}{c}\text { Validator } \\
\mathbf{3}\end{array}$ \\
\hline $\begin{array}{c}\text { Total Score } \\
\text { Maximum } \\
\text { Score }\end{array}$ & 86 & 88 & 87 \\
Percentage & 105 & 105 & 105 \\
\hline
\end{tabular}

In this content validation there are several suggestions from the validator, including validator 1: (1) The image on the hydrostatic pressure section should be replaced with a diver's image only, because it is interesting and close to students' lives, this is intended to represent the initial concept; (2) videos should use videos recorded by media creators. For validator 2 , suggesting that the next and next button navigation buttons should be considered again, because they are double functions. Then from validator 3 there is no suggestion of improvement.

Furthermore, the results of media validation by the three validators showed that the media was very feasible with an average percentage of $89.7 \%$. In detail shown by Table 7 .

Table 7. The results of media validation by the three validators

\begin{tabular}{cccc}
\hline & $\begin{array}{c}\text { Validator } \\
\mathbf{1}\end{array}$ & $\begin{array}{c}\text { Validator } \\
\mathbf{2}\end{array}$ & $\begin{array}{c}\text { Validator } \\
\mathbf{3}\end{array}$ \\
\hline $\begin{array}{c}\text { Total Score } \\
\text { Maximum } \\
\text { Score }\end{array}$ & 121 & 126 & 130 \\
Percentage & 140 & 140 & 140 \\
\hline
\end{tabular}

In media validation there are several suggestions from validators, including validator 1: (1) it is better to use images that are closer to children's lives; (2) has not seen the multi-representation. As for validator 2, he suggested: (1) it is better to replace some images into images that are closer to life, for example in hydrostatic, use images of duck feet and chicken feet; (2) it is better to reflect on the answer using multi-representation understanding; and (3) creative questions should be given, such as games and so on, which make students interested in learning. As for the validator, 3 suggestions are: (1) correcting some typos, (2) giving creative questions, such as games and so on, which make students interested in learning.

Every suggestion from the validator in the context of content and media has been improved by the researchers before conducting a small-scale trial to 8th grade junior high school students.

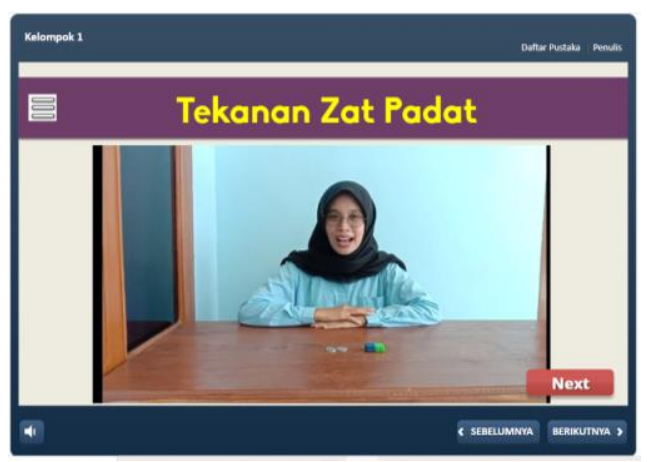

Figure 2. Original video display by media developer



Figure 3. Improvements from suggestions to provide practice questions in the form of games

\section{Implementation}

Implementation is carried out after the suggestions from the validator are corrected. A small-scale trial was conducted on 7 students in one of the junior high schools in Pati Regency. Before learning, students are given a pretest with a total of 5 questions. Here are some examples of pre-test questions and student answers as shown in Table 8. 
Table 8. Pre-test Questions and Student Answers

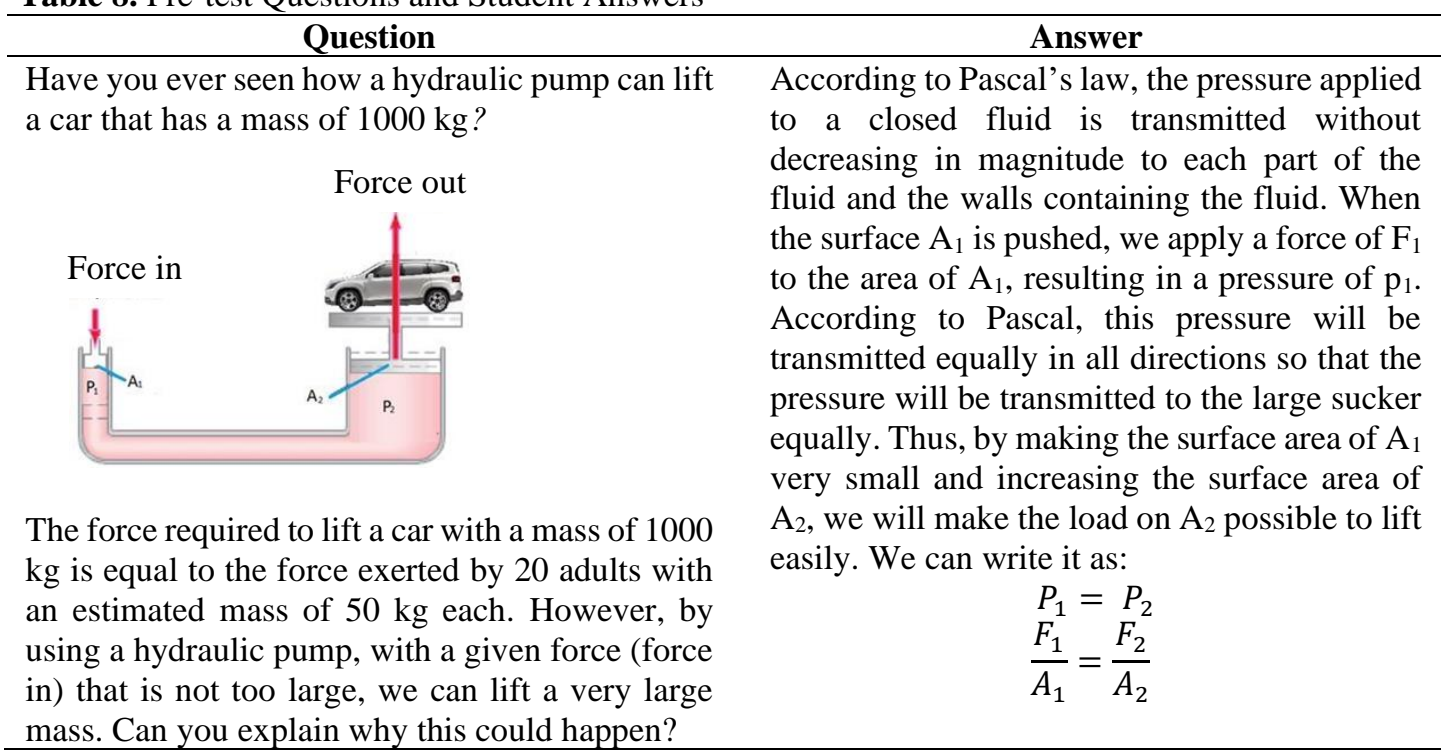

After the pre-test, students were given learning using MultiRepresentation-Based Interactive Media to improve scientific literacy. Learning with this media is designed for students to complete each stage in order to proceed to the next stage. Because this media has been set with automatic lock if students skip each stage. After finishing all learning students are given a post-test with the same questions as the pre-test questions.

Then, through the pre-test and post-test scores, an analysis was performed to know whether the sample is normally distributed or not. The test used one-sample kolmogorov smirnov test, the result is described in table 9.

Table 9. One-Sample Kolmogorov-Smirnov Test

\begin{tabular}{llr}
\hline N & Mean & $\begin{array}{r}\text { Unstandardize } \\
\text { d Residual }\end{array}$ \\
\hline Normal Parameters & 7 \\
Most Extreme Differences & Std. Deviation & .0000000 \\
& Absolute & 3.80040905 \\
& Positive & .208 \\
Test Statistic & Negative & .145 \\
Asymp. Sig. (2-tailed) & & -.208 \\
\hline a. Test distribution is Normal. & .208 \\
b. Calculated from data. & $.200^{\mathrm{c}, \mathrm{d}}$ \\
c. Lilliefors Significance Correction. \\
d. This is a lower bound of the true significance.
\end{tabular}

The data collected is calculated for normality using the One-Sample Kolmogorov-Smirnov Test. The results of the calculation of the significance value of 0.2 , if a significance level of 0.05 is used, so $0.2>0.05$, it can be concluded that the data is normally distributed. Because the sample is normally distributed, so we use the parametric statiscic to test the mean diference. Using the Paired Samples Test, a significance value of 0.000 was obtained. With a significance of 0.05 , then 0.000 
$<0.05$ it can be said that there is an effect/difference in the average of both pre-test and post test results. The paired ttest result can be seen in table 10 .

Table 10. Paired Samples Test

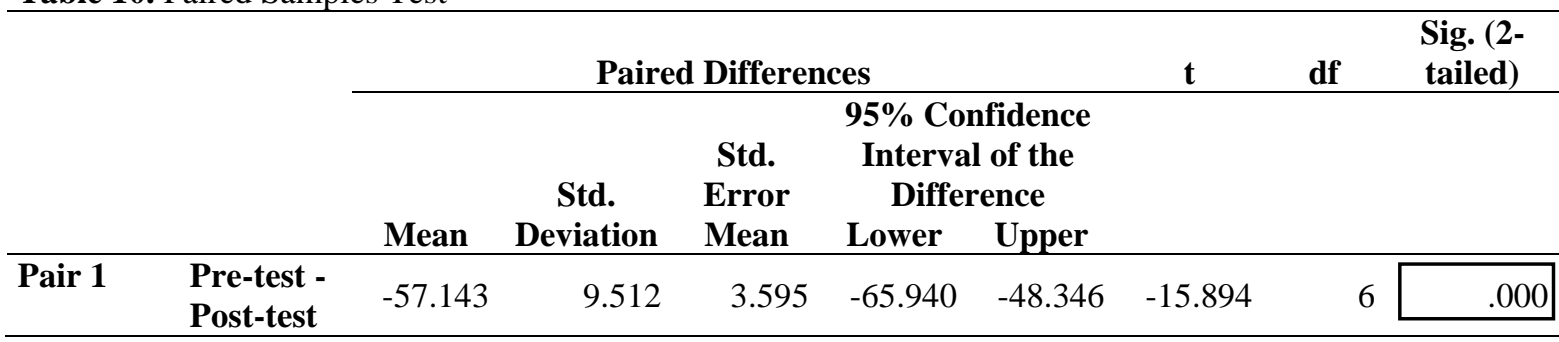

Based on this, it can be concluded that this interactive media can improve students' scientific literacy skills. This is in line with previous research conducted by Wibowo et al., (2020).

\section{Conclusion}

The results of media and content validation by the validator show that the media is very suitable to be used as interactive multimedia in learning. The results of the implementation of interactive media also show that this media can improve students' scientific literacy skills. This is evidenced by the results of the paired t-test which shows a value of 0.000 which means it is smaller than 0.05 . So it can be concluded that there is an average difference between the results of the pretest and post-test as the effect of using interactive multimedia.

\section{REFERENCES}

Ariani, R., Ratnawulan, \& Fauzi, A. (2020). The Practicality of Interactive Multimedia Integrated Science Based on Guided Inquiri with Theme Energy in The Life That Integrates of Learning for The 21st Century. 3rd International Conference on Research and Learning of Physics 2020, 1-8. https://doi.org/doi:10.1088/17426596/1876/1/012051

Atmawarni. (2011). Penggunaan Multimedia Interaktif Guna
Menciptakan Pembelajaran yang Inovatif di Sekolah. Jurnal Ilmu Sosial-Fakultas ISIPOL UMA, 4(1), 20-27.

Furwati, S., Sutopo, \& Zubaidah, S. (2017). Conceptual Understanding and Representation Quality on Newton's Laws through MultiRepresentation Learning. Jurnal Pendidikan Sains, 5(3), 80-88.

Gormally, C., Brickman, P., \& Lutz, M. (2012). Developing a Test of Scientific Literacy Skills (TOSLS): Measuring Undergraduates' Evaluation of Scientific Information and Arguments. CBE Life Sciences Education, 11(4), 364-377. https://doi.org/10.1187/cbe.12-030026

Hakim, S., Effendi, E., \& Widayanti, W. (2020). Perbandingan Model Group Investigation dan Number Head Together: Analisis terhadap Hasil Belajar. U-Teach: Journal Education of Young Physics Teacher, 1(1), 1117.

https://doi.org/10.30599/uteach.v1i1. 18

Haqiqi, A. K. (2018). Analisis Faktor Penyebab Kesulitan Belajar IPA Siswa SMP Kota Semarang. Jurnal Pendidikan Sains \& Matematika, 6(1), 37-43.

Istiyono, E. (2018). The developing of creative thinking skills test based on modern test theory in physics of 
senior high schools. Cakrawala Pendidikan, 37(2), 190-200. https://doi.org/https://doi.org/10.218 31/cp.v37i2.19233

Kementerian Pendidikan dan Kebudayaan. (2017). Materi Pendukung.

Kristyasari, M. L., Yamtinah, S., Utomo, S. B., Ashadi, \& Indriyanti, N. Y. (2018). Gender Differences in Students' Science Literacy towards Learning on Integrated Science Subject. ICRIEMS 5, 1-8. https://doi.org/doi:10.1088/17426596/1097/1/012002

Latifah, S., Susilowati, N. E., Khoiriyah, K., Saidy, S., Yuberti, Y., \& Rahayu, R. (2019). Self-Efficacy: Its Correlation to the Scientific-Literacy of Prospective Physics Teacher. Journal of Physics: Conference Series, 1-8. https://doi.org/10.1088/17426596/1155/1/012015

Mahbub, M. Z., Kirana, T., \& Poedjiastoeti, S. (2016). Development Of STAD Cooperative Based Learning Set Assisted With Animation Media To Enhanche Students' Learning Outcome in MTS. Jurnal Pendidikan IPA Indonesia, $5(2)$, 247-255. https://doi.org/10.15294/jpii.v5i2.60 04

Makhrus, M., Wahyudi, W., \& Zuhdi, M. (2021). Students' Conceptual Understanding through Implementation of LiveWire in Basic Electronics Virtual Experiment. Jurnal Penelitian Pendidikan IPA, $7(2)$, 249-254. https://doi.org/10.29303/jppipa.v7i2. 705

Murtono, Setiawan, A., \& Rusdiana, D. (2014). Fungsi Representasi dalam Mengakses penguasaan Konsep Fisika Mahasiswa. JRKPF UAS, l(2). Organisation for Economic Cooperation and Development (OECD). (2016). Snapshot of performance in mathematics, reading and science.

Prastikawati, D., Anisatur Rofiqah, S., \& Widayanti, W. (2020). Model Pembelajaran STAD Melalui Media Kotak Kartu Misterius (Kokami): Penerapan Terhadap Hasil Belajar Fisika Smp Materi Usaha Dan Pesawat Sederhana. U-Teach: Journal Education of Young Physics Teacher, 1(2), 77-85. https://doi.org/10.30599/uteach.v1i2. 27

Rahmawati, I., Hidayat, A., \& Rahayu, S. (2016). Penguasaan Konsep IPA Siswa SMP pada Materi Tekanan pada Zat Cair dan Aplikasinya. Jurnal Pendidikan Sains, 4(3), 102112.

Ristanto, R. H., Miarsyah, M., Muharomah, D. R., Astuti, T. A., Aini, S., \& Prihatin, A. I. (2020). Light-board: Simple media to learn photosynthesis concepts. International Journal of Advanced Trends in Computer Science and Engineering, 9(1), 299-303. https://doi.org/10.30534/ijatcse/2020 /45912020

Sari, N. P., Suhirman, S., \& Walid, A. (2020). Pengembangan Modul Pembelajaran IPA Berbasis Etnosains Materi Interaksi Makhluk Hidup dengan Lingkungannya untuk Menanamkan Jiwa Konservasi Siswa Kelas VII SMP. Bio-Edu: Jurnal Pendidikan Biologi, 5(2), 63-74. https://doi.org/10.32938/jbe.v5i2.554

Sarwi, S., Yusnitasari, A., \& Isnaeni, W. (2020). Concept Mastery of Ethnoscience-Based Integrated Science and Elementary Students' Life Skills Using Guided Inquiry. Advances in Social Science, Education and Humanities Research, 443(Iset 2019), 517-522.

Shabrina, \& Kuswanto, H. (2018). Android-assisted mobile physics learning through indonesian batik culture: Improving students' creative 
thinking and problem solving. International Journal of Instruction, 11(4), 287-302. https://doi.org/10.12973/iji.2018.114 $19 \mathrm{a}$

Syafitri, Q., Mujib, M., Netriwati, N., Anwar, C., \& Wawan, W. (2018). The Mathematics Learning Media Uses Geogebra on the Basic Material of Linear Equations. Al-Jabar: Jurnal Pendidikan Matematika, 9(1), 9-18.

https://doi.org/10.24042/ajpm.v9i1.2 160

Wahyudi, W., Waluya, S., Suyitno, H., \& Isnarto, I. (2020). Students' creative thinking ability and thinking schemata in cool-critical-creativemeaningful (3CM) learning. International Journal of Innovation, Creativity and Change, 11(10).

Wibowo, T. H., Sunyono, \& Rudibyani. (2020). Perception of Teachers and Students by Using Interactive Multimedia to Improve Science Literacy and Self-Efficacy. Jurnal Ilmiah Pendidikan Dasar, 12(2), 7580.

Widodo, W., Sudibyo, E., Suryanti, Sari, D. A., Inzanah, \& Setiawan, B. (2020). d Interactive Multimedia in Improving Generation Z's Scientific Literacy. Jurnal Pendidikan IPA Indonesia, 9(2), 248-256.

Yanti, F. A., Kuswanto, H., Mundilarto, Jumadi, \& Rosa, F. O. (2019). Development of analog material based physics module to improve concept understanding and creative thinking. International Journal of Scientific and Technology Research, 8(10), 1244-1248.

Zhou, Q. (2021). Development of creative thinking skills through aesthetic creativity in middle school educational music course. Thinking Skills and Creativity, 40, 40. 